\title{
Tindakan Preventif atas Penyebaran Covid-19 dalam Perspektif Hadis
}

\author{
Eko Zulfikar \\ Institut Agama Islam Negeri (IAIN) Tulungagung; ekozulfikar2020@gmail.com \\ ${ }^{*}$ Correspondence
}

Received: 2020-06-30; Accepted: 2020-09-08; Published: 2020-09-30

\begin{abstract}
This paper discusses the concept of science in hadith. In appropriation, this paper examines how to prevent the preventive distribution of Covid-19 as based on the Prophet's hadith. In this research, the method used is thematic. Meanwhile, to understand related traditions' content, this paper employed ma'ani al-hadith explicitly with an intertextuality approach. Thus, the discussion results about thematization of the hadith indicate that: Islam had provided signs of preventive action for all kinds of disasters or diseases long before Covid-19 appeared. Explanation of the Prophet's hadith related to preventive measures for the spread of Covid-19, imposing to stay at home, to keep social distancing, to multiply alms, and to always in a clean condition by maintaining ablution, maintaining immunity, and always praying for help from Allah SWT. These efforts must be carried out intensively and collectively by every citizen so that the spread of Covid-19 is immediately stopped.
\end{abstract}

Keywords: Preventive actions; Hadith of the Prophet; Covid-19.

\begin{abstract}
Abstrak: Tulisan ini mengungkap bagaimana tindakan preventif atas penyebaran Covid-19 berdasarkan hadis Nabi. Dalam peneltian ini metode yang digunakan adalah tematik. Sementara untuk memahami kandungan hadis yang berkaitan, tulisan ini secara spesifik mengkaji ma'āni alhadith dengan pendekatan interkontekstualitas. Hasil pembahasan secara tematik mengindikasikan bahwa, Islam memberi rambu-rambu tindakan preventif atas segala macam bencana atau penyakit, jauh sebelum Covid-19 muncul. Penjelasan hadis Nabi terkait tindakan preventif atas penyebaran Covid-19 antara lain; memberlakukan berdiam di rumah, social distancing (pembatasan sosial), memperbanyak sedekah, memelihara wudhu, menjaga imunitas tubuh serta memohon pertolongan kepada Allah Swt. Upaya-upaya ini merupakan ikhtiar yang harus dilakukan secara intensif dan kolektif oleh setiap warga, agar penyebaran Covid-19 segera terhentikan.
\end{abstract}

Kata kunci: Tindakan preventif; hadis Nabi; Covid-19.

\section{Pendahuluan}

Di tengah maraknya wabah Covid-19 yang terjadi saat ini, para pakar baik dari unsur tenaga medis, ilmuan, pemerintah, dan bahkan ulama, mencoba mencari jalan keluar agar terhindar dari virus tersebut. Mereka berupaya dengan tugas dan keahlian masing-masing untuk menanggulangi tersebarnya wabah Covid-19. Pemerintah dalam hal ini berusaha mencegah virus tersebut dengan berbagai macam upaya, mulai dari sosialisasi dan membuat website tersendiri pada halaman khusus tentang Covid-19 (Telaumbanua, 2020). Website tersebut di-update setiap hari dengan menampilkan langkah penting, materi edukasi, tanya jawab, serta jumlah data orang yang positif terinfeksi, kesembuhan, dan bahkan yang sudah meninggal.

Dalam sejarah peradaban manusia, virus merupakan wabah atau penyakit yang sebenarnya sudah pernah terjadi dari masa ke masa. Dari zaman para Nabi, para sahabat, dan generasi setelahnya, 
virus atau wabah ini pernah terjadi dengan istilah dan model penyakit yang berbeda, sehingga upaya pencegahannya pun juga berbeda. Beberapa wabah besar yang pernah melanda di kawasan Laut Tengah dan Timur Tengah pada zaman itu, di antaranya adalah Wabah Yustinianus terjadi sekitar tahun $541 \mathrm{M}$ (sekitar 30 tahun sebelum kelahiran Nabi Muhammad). Wabah ini melanda Konstantinopel, ibukota Byzantium (Rum), dan wabah tahun 627 M di Kerajaan Persia Sasania. Kedua wabah itu melemahkan dua negara besar Byzantium dan Sasania, sehingga sangat mendukung kebangkitan daulat Islam yang didirikan Nabi Muhammad, yang mengalahkan Byzantium di Yarmūk dan Sasania di al-Qādisiyah. Namun sesudahnya, daulat Islam sempat terjangkit wabah Emmaus (ța ' $\bar{u} n$ amwas) yang melanda Palestina dan Shām yang baru direbut dari Byzantium. Wabah tersebut telah menewaskan cukup banyak orang termasuk sahabat Nabi, Abū ‘Ubaidah bin al-Jarrāḥ (Primandya, 2020; Rusdi, 2020) .

Kehadiran wabah Covid-19 saat ini tidak dapat dipungkiri keganasannya. Ia merupakan virus yang harus dilawan, tidak boleh merajalela, apalagi sampai menyebar dengan merenggut banyak nyawa. Cara untuk melawan virus tersebut dapat bervariasi, namun pada intinya harus berupaya untuk mencegah secara maksimal demi menjaga kemaslahatan sosial. Dalam proses menerapkan tindakan preventif atas penyebaran Covid-19 ini, berbagai usaha yang digaungkan pemerintah harus diimbangi dengan kesadaran setiap warga. Ketika pemerintah sudah menjalankan tugasnya sebagai antisipasi terhadap pencegahan wabah Covid-19, maka sebagai warga masyarakat yang baik juga harus memberikan atensi khusus agar bisa mengikuti instruksi dari pemerintah tersebut.

Sejauh sebelum Covid-19 ini muncul, sebenarnya Islam telah mengajarkan cara mencegah dan mengantisipasi segala penyakit sebagaimana diajarkan Nabi Muhammad. Tuntunan Nabi tersebut dapat dijadikan patokan dasar untuk melawan dan menghentikan Covid-19 yang semakin menyebar luas (Qudsy \& Sholahuddin, 2020). Tulisan ini secara spesifik membahas tindakan preventif atas penyebaran Covid-19 sejauh yang direkam hadis Nabi. Karena uraiannya mengaitkan sebuah tema yang ada dalam hadis, maka metode yang digunakan merujuk pada kerangka metode maud $\bar{u}^{\prime} \bar{\imath}$ (tematik). Selain itu, tulisan ini spesifik mengkaji secara ma'änil hadìth dengan pendekatan interkontekstualitas, menggunakan studi pustaka (library research) murni, dan menitik-beratkan hadishadis berkaitan sebagai data primer yang semuanya mengacu pada tema utama, yakni tindakan preventif atas penyebaran Covid-19.

\section{Analisis Preventif covid-19 Perspektif Hadis}

\section{Sejarah dan Bahaya Covid-19}

Pandemi Coronavirus atau dikenal sebagai pandemi Covid-19 adalah salah satu peristiwa yang muncul di akhir tahun 2019. Virus ini ada disebabkan oleh Coronavirus jenis baru yang diberi nama SARS-CoV-2. Ia familiar sangat mematikan dan sudah menyebar ke seluruh dunia. Awal mula Covid19 terdeteksi adalah di Kota Wuhan, Provinsi Hubei, Tiongkok pada bulan Desember Tahun 2019, dan ditetapkan sebagai pandemi oleh Organisasi Kesehatan Dunia (WHO) pada 11 Maret 2020. WHO (World Health Organization) telah memberikan rincian atas singkatan Covid-19; CO mengacu pada corona, VI mengarah ke virus, lalu D adalah disease atau penyakit, dan 19 merujuk kepada tahun di mana wabahnya pertama kali diidentifikasi pada 31 Desember 2019. Pemberian akronim Covid-19 ini dinilai lebih mudah disebut dan diingat (Shereen, Khan, Kazmi, Bashir, \& Siddique, 2020)

Dari perspektif historis, virus Corona pertama menginfeksi manusia pada pertengahan tahun 1960. Banyak varian virus Corona yang dapat menginfeksi manusia, di antaranya adalah 229E (alpha Coronavirus), NL63 (alpha Coronavirus), OC43 (beta Coronavirus), HKU1 (beta Coronavirus), MERS$\mathrm{CoV}$ (beta Coronavirus yang menyebabkan MERS), SARS-CoV (beta Coronavirus yang menyebabkan SARS), dan SARS-CoV-2 (novel Coronavirus yang menyebabkan Covid-19)(Mukaromah, 2020). Penamaan Corona merupakan istilah yang berasal dari bahasa latin yang berarti mahkota. Hal ini mengacu pada model struktur virus Corona yang dikelilingi oleh bentuk melingkar seperti mahkota.

Virus SARS-CoV-2 atau virus Corona diduga keras bisa menyebar ke banyak orang terutama melalui percikan pernafasan (droplet) yang dihasilkan selama batuk. Percikan ini juga dapat terbentuk 
dari bersin dan pernapasan normal. Selain itu, virus dapat menyebar akibat menyentuh permukaan benda yang terkontaminasi, dan kemudian menyentuh wajah seseorang. Penularan wabah Covid-19 ini terjadi saat orang yang menderitanya memiliki gejala, meskipun dalam penularannya bisa saja terjadi sebelum gejala itu muncul. Periode waktu antara terpapar virus dan munculnya gejala adalah sekitar 5 hari, namun dapat juga berkisar dari 2 hingga 14 hari. Adapun gejala umum yang dirasakan adalah demam, batuk, dan sesak nafas (Nugroho et al., 2020).

Sars-Cov2 yang merupakan penyebab Covid-19 adalah virus yang dapat masuk dan menyerang sistem pernafasan manusia. Proses reaksinya dimulai dari hidung kemudian menuju ke paru-paru yang memungkinkan manusia menghirup oksigen dan mengeluarkan karbon dioksida. Sars-Cov2 masuk ke pernafasan ketika manusia menghirup udara yang sudah terkontaminasi oleh virus, baik melalui media tangan atau benda yang sudah terkontaminasi. Setelah berpengaruh pada paru-paru, tenggorokan dan saluran udara, virus ini bekerja dengan cara membajak sel-sel yang ada di dalam tubuh manusia, kemudian setelah itu masuk ke dalam sel tersebut dan mereproduksi diri. Setelah berkembang menjadi lebih banyak, virus akan menyebar ke sel-sel baru yang ada di sekitar sel tempat ia tinggal (Azanella, 2020).

Sebuah penelitian dari Johns Hopkins Bloomberg School of Public Health memperkirakan periode rata-rata inkubasi virus Corona terjadi selama 5 hari. Temuan itu sekaligus sebagai dasar penetapan masa karantina selama 14 hari oleh keputusan Pusat Pengendalian dan Pencegahan Penyakit Amerika Serikat (AS). Termasuk masa karantina 14 hari juga, ditetapkan sebagai keputusan awal di Indonesia dalam memutus rantai menyebarnya Covid-19. Analisis tersebut menunjukkan bahwa sekitar 97,5 persen orang yang mengalami gejala infeksi Covid-19 bisa dinyatakan positif dalam 11,5 hari setelah terpapar. Selain itu, para peneliti memperkirakan setiap 10 ribu orang yang dikarantina selama 14 hari, hanya sekitar 101 orang yang akan mengalami gejala setelah dilepaskan dari karantina. Dalam penelitian itu, para peneliti menganalisis 181 kasus dari China dan negara-negara lain yang terdeteksi sebelum 24 Februari 2020. Selain itu, peneliti juga menganalisis laporan dari media, hingga kemungkinan tanggal paparan dan gejala onset (CNN Indonesia, 2020).

engan demikian, bahaya Covid-19 ini tidak diragukan lagi eksistensinya. Ia bermula sekitar tahun 1960, di mana varian virus ini sangat banyak dan mampu dengan mudah menginfeksi manusia. Virus Corona jenis SARS-CoV-2 adalah bukti nyata yang sampai saat ini mampu mengguncangkan dunia. Banyak korban nyawa melayang akibat keganasan Covid-19 ini. Bahkan disebutkan dalam berbagai media, bahwa Covid-19 telah memakan korban hingga ratusan ribu di seluruh dunia. Hal ini menunjukkan bahwa Covid-19 sangat berbahaya yang perlu diantisipasi serta ditanggulangi agar tidak semakin menyebar dan banyak korban berjatuhan.

Berikut adalah gambar penampakan sampel virus Covid-19 yang diambil dari Rocky Mountain Laboratories (RML) di Institut Nasional Alergi dan Penyakit Menular, Montana, AS dari salah satu pasien yang terinfeksi Covid-19 (Putri, 2020).

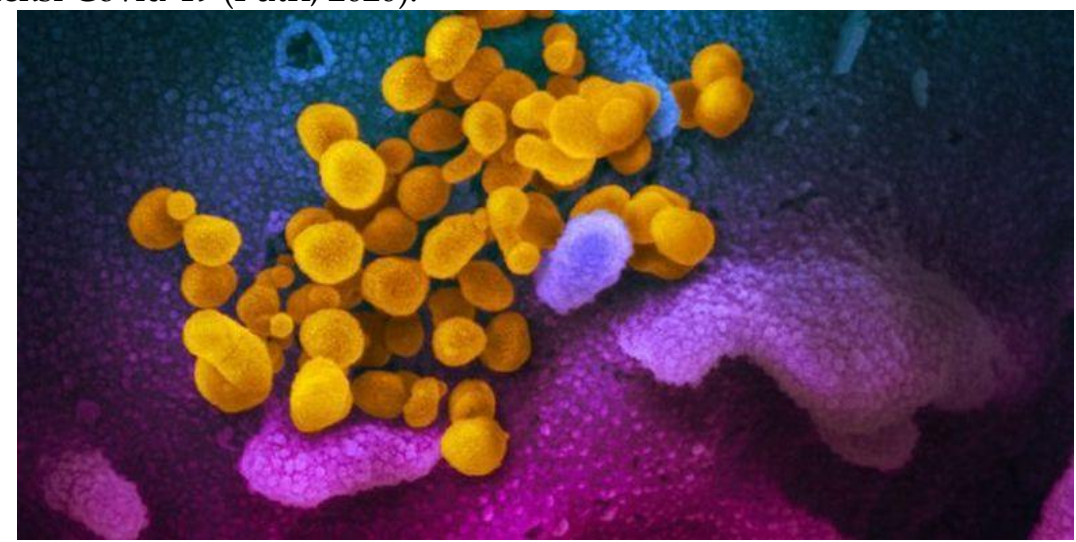

Gambar 1 Virus Corona Wuhan atau Covid-19 (kuning) di antara sel manusia (biru, merah muda dan ungu). 


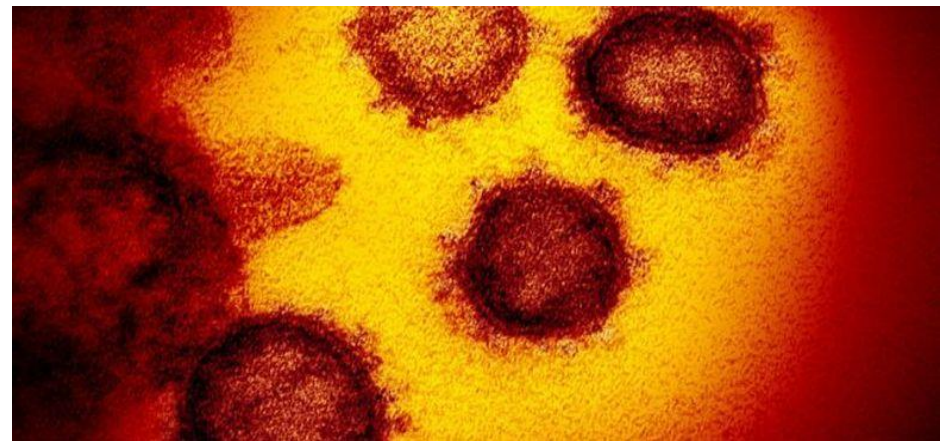

Gambar 2 gambar mikroskop elektron transmisi yang menunjukkan Coronavirus baru yang muncul dari permukaan sel manusia.

\section{Tindakan Preventif atas Penyebaran Covid-19}

Sebagaimana penjelasan sebelumnya, Covid-19 ini sangat ganas dan membahayakan bagi kehidupan seluruh dunia. Penyakit yang disebabkan virus jenis baru ini semakin meluas dan merebak dengan cepat. Menurut data terakhir yang dipublikasikan oleh Kementrian Kesehatan Republik Indonesia, sudah lebih dari 16.000 orang yang positif terinfeksi virus Corona di Indonesia dan ada indikasi terus bertambah (Kementerian Kesehatan Republik Indonesia, 2020). Indonesia telah mengambil sikap dengan menggaungkan beberapa keputusan agar dipedomani seluruh rakyat Indonesia (Zahrotunnimah, 2020). Hal ini untuk mencegah sekaligus menghentikan penyebaran Covid-19 yang semakin tidak terbendung. Di samping itu, penjelasan hadis Nabi juga memberikan rambu-rambu untuk menanggulangi bahaya penyakit agar tidak cepat menular. Hal ini penting untuk ditindak-lanjuti sekaligus sebagai tindakan preventif atas penyebaran Covid-19. Paling tidak ada enam tindakan preventif menurut hadis agar Covid-19 tidak semakin menebar eksistensi-nya di seluruh dunia, yaitu:

Stay at Home (berdiam di Rumah)

Dalam upaya menangani wabah Covid-19 yang semakin meluas, pemerintah telah merespon dengan melakukan tindakan preventif untuk menghadapi ganasnya penyakit tersebut. Salah satu yang dilakukan adalah memberi himbauan untuk menjalankan aktivitas dari rumah saja (stay at home), khususnya para pekerja. Ini dilakukan untuk meminimalisir agar Covid-19 tidak mudah menular dan para masyarakat tidak terjangkit penyakit ini. Pemerintah menyerukan, masyarakat boleh untuk keluar rumah apabila ada urusan penting dan bersifat terpaksa (darurat). Namun aktivitas dadakan di luar rumah ini juga harus memedomani anjuran dan intrusksi yang telah disuarakan, agar penularan Covid-19 dapat terbendung dengan maksimal.

Berkaitan dengan upaya berdiam di rumah, hadis Nabi juga menegaskan tindakan preventif untuk menghadapi penularan wabah Covid-19, antara lain;

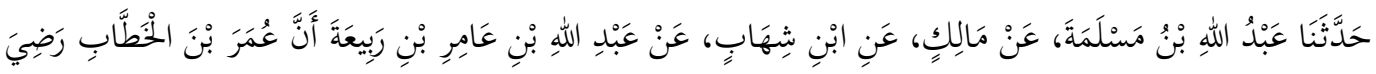

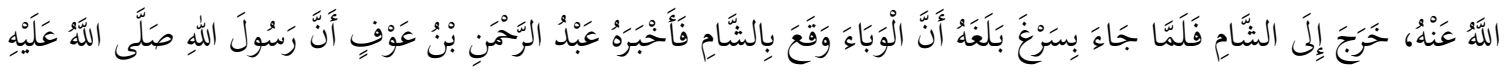

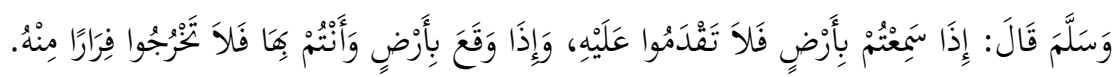

“Dari 'Abdullāh bin 'Āmir bin Rabī'ah bahwa 'Umar bin Khațạāb pergi menuju Shām. Ketika sempai di daerah Sargh, 'Umar mendapat kabar bahwa Shām terkena wabah. Kemudian 'Abdurrahmmān bin 'Auf berkata pada 'Umar bahwa Nabi Muhammad Saw pernah bersabda: "Jika kalian mendengar kabar di suatu daerah (terkena wabah) janganlah kalian memasukinya. Jika wabah 
berada di suatu daerah sedangkan kalian di dalamnya, maka janganlah kalian keluar dari daerah itu untuk menghindari wabah." (al-Bukhari, 1422 H, hlm. 26).

Para ulama berbeda pendapat ketika memahami kata $w a b \bar{a}^{\prime}$ dalam hadis di atas. Di dalam Sharh al-Qasțalānī dijelaskan, bahwa kata $w a b \bar{a}^{\prime}$ berarti penyakit yang umum, namun khusus dalam hadis tersebut $w a b \bar{a}^{\prime}$ berarti penyakit tă $\bar{u}$ un yang biasa disebut dengan țā'ūn amwas (Al-Qasthalaniy, $1323 \mathrm{H}$, hlm.167). Berbeda dengan penjelasan Imām Nawawī yang menuturkan bahwa semua țā'ūn adalah $w a b \bar{a}^{\prime}$, namun bukan berarti setiap $w a b \bar{a}^{\prime}$ adalah țā'ūn . Daerah Shām pada saat itu sedang terkena wabah țầūn amwas.

Dalam men-syarah hadis di atas, Imām Nawawī menjelaskan lebih lanjut perbedaan antara țā'ūn dan $w a b \bar{a}^{\prime}$. Yang dimaksud țā'ūn menurutnya adalah luka yang keluar dari tubuh yang berada di siku, ketiak, tangan, jari, dan seluruh tubuh. Luka tersebut menimbulkan benjolan dan menyebabkan sakit yang luar biasa. Lukanya seperti terkena api, sekitar luka berwarna hitam, hijau atau kemerahan ungu pekat, serta bisa menyebabkan jantung berdetak lebih cepat dan muntah-muntah. Sementara yang dimaksud $w a b \bar{a}^{\prime}$ adalah penyakit yang menyerang banyak orang di belahan bumi (baca: wabah). Penyakit ini tidak sama dengan penyakit yang lainnya, karena penyakit yang di derita pada saat itu berbeda dan tidak terjadi di waktu yang lain (Al-Nawawi, 1392, hlm. 364).

Dari sini dapat dimengerti bahwa ță'ūn semacam penyakit kulit yang mematikan. Sementara $w a b \bar{a}^{\prime}$ lebih mengacu pada penyakit yang menyerang masyarakat pada suatu daerah. Mengacu pada eksistensi pandemi Covid-19 saat ini, bila dikaitkan dengan istilah $w a b \bar{a}^{\prime}$ dan $t \bar{a}^{\prime} \bar{u} n$, maka yang lebih sesuai adalah dengan menyebutnya sebagai $w a b \bar{a}^{\prime}$ (wabah). Hadis di atas penting untuk diteladani, bahwa tinggal di rumah atau tidak keluar rumah untuk menghindari penularan penyakit, termasuk wabah Covid-19 merupakan tindakan preventif yang diajarkan oleh Nabi. Dipertegas lagi dalam hadis lain:

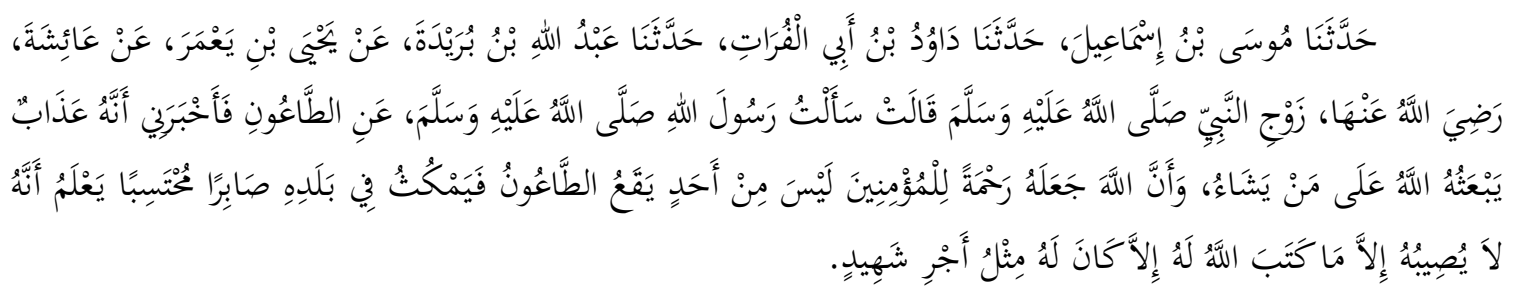

Dari 'A' 'ishah istri Nabi SAW ia berkata: Saya bertanya kepada Rasulullah SAW tentang wabah penyakit Tha'un, maka Nabi mengkabarkan kepadaku; Sungguh wabah penyakit Tha'un itu adalah siksa yang dikirimkan Allah kepada siapa saja yang Dia kehendaki. Tetapi Allah juga menjadikannya sebagai rahmat bagi kaum mukminin (yang bersabar menghadapinya). Maka tidak ada seorang hamba ketika terjadi wabah penyakit Tha'un tetap tinggal di negerinya (di rumahnya) dengan sabar, mengharap pahala dari Allah (atas kesabarannya) dan mengetahui bahwa tidak ada yang menimpanya kecuali apa yang telah Allah tetapkan, melainkan ia akan memperoleh pahala seperti orang yang syahid(al-Bukhari, 1422, hlm. 175).

Terkait dengan hadis ini, Ibnu Ḥajar al-'Asqalānī memberikan konklusi bahwa siapa-pun yang berusaha menghindari wabah ța'un dengan cara bersabar di dalam rumah (stay at home), mengharapkan ridha Allah, dan senantiasa penuh percaya dengan takdir Allah, maka ia akan mendapatkan pahala syahid, meski ia tidak mati karena wabah țā'ūn (al-'Asqalani 1982, juz 10, hlm. 194).

Penjelasan hadis di atas sebenarnya berbicara tentang wabah penyakit țā'ūn, namun esensinya dapat dijadikan teladan dalam menghadapi wabah Covid-19. Oleh karenanya, tinggal di rumah adalah salah satu tindakan yang tepat untuk mencegah penyebaran Covid-19 dalam perspektif hadis. Selain itu, Allah telah memberi pahala jika usaha tinggal di rumah itu dilakukan dengan sabra, dan meninggal dunia pun disetarakan dan diberi pahala syahid. Ibnu Bațțāl mengutip pendapat al-Ṭabarī ketika menjelaskan makna hadis di atas, ia mengatakan: 
"Dalam hadits di atas, ada petunjuk tentang kewajiban seseorang menjaga diri dari perkaraperkara buruk sebelum terjadinya, menjauhi hal-hal yang dikuatirkan sebelum menyerangnya, bersabar dan tidak mengeluh setelah tertimpanya. Oleh karena itu, Nabi SAW melarang orang yang tidak berada di dalam daerah wabah penyakit untuk memasuki daerah terjadinya wabah penyakit, dan melarang orang yang sudah berada di dalam daerah wabah penyakit untuk keluar dari daerah tersebut. Demikian pula wajib hukumnya, bagi setiap orang yang kuatir kepada sesuatu untuk menempuh jalan dalam menghadapinya, sebagaimana jalan yang ditempuh ketika menghadapi wabah penyakit țā'ün" (Ibnu Baththal, 2003, hlm. 423).

Dengan demikian, dapat dimengerti bahwa Islam telah memberi pelajaran penting dalam menghadapi wabah penyakit. Tinggal di rumah sebagaimana diinstruksikan pemerintah untuk menanggulangi marakanya Covid-19, sama sekali tidak kontradiktif dengan ajaran Nabi. Bahkan selama Covid-19 masih tinggi, Nabi menganjurkan agar tetap tinggal di rumah dengan bersabar, berikhtiar menghindarinya, dan ketika terjangkit wabah tersebut sampai dengan akhir hayat, maka termasuk meninggal dengan cara syahid. Dengan kata lain, tindakan preventif atas penyebaran Covid19 yang dijelaskan hadis Nabi sangat berhubungan, bersinergi, berkorelasi, dan memiliki relevansi kuat dengan apa yang digaungkan pemerintah terkait anjuran tinggal di rumah.

\section{Social Distancing (Pembatasan Sosial)}

Dalam konteks wabah Covid-19 yang terus merambah: pemerintah juga menginstruksikan kepada masyarakat agar senantiasa menerapkan social distancing atau pembatasan sosial. Ini merupakan salah satu langkah penanggulangan dan pengendalian infeksi Covid-19 dengan menganjurkan orang sehat untuk membatasi datang ke tempat ramai dan kontak langsung dengan orang lain. Berkenaan dengan ini: al-Auzā'î̀, pakar hadis dari kalangan tabi'in menegaskan tentang kesehatan, ia mengungkapkan;

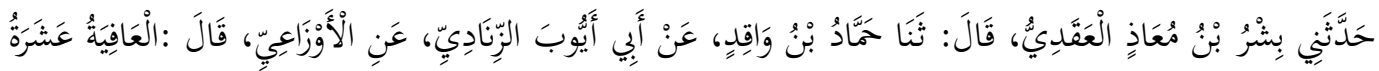

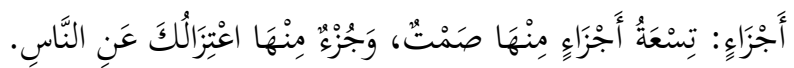

“Al-Auzā'ī ia berkata, kesehatan itu memerlukan sepuluh hal, sembilan di antaranya berdiam dan satu yang lainnya menjauhkan diri dari kerumunan manusia." (Abū al-Dunyā' 2003, hlm. 37)

Pesan al-Auzā'î tersebut sangat relevan dengan kondisi saat ini, bahwa menghindari kerumunan massa merupakan salah satu langkah penanggulangan penyebaran Covid-19. Bahkan Ibn Ḥajar al'Asqalānī mengisahkan suatu cerita tentang dampak buruk berkumpulnya banyak manusia dalam satu tempat ketika sedang terjadi wabah penyakit meski tujuannya untuk berdo'a bersama, menurutnya:

"Berdo'a agar terhindar dari wabah penyakit itu tidak dilarang sama sekali, dan tidak pula bertentangan dengan apa yang telah ditakdirkan oleh Allah. Akan tetapi berkumpul untuk melakukan do'a bersama sebagaimana yang dilakukan -dalam shalat Istisqa'- saat dilanda penyakit wabah tă $\bar{\prime} u \bar{n}$ besar-besaran pada tahun $749 \mathrm{H}$ di Damaskus-Syria itu adalah perbuatan bid'ah. Aku telah membaca dalam Juz al-Manbiji setelah penolakan beliau terhadap pengumpulan orang dalam satu tempat. Beliau berkata, "Mereka berkumpul dan berteriak seraya berdo'a dengan suara yang tinggi. Hal itu terjadi pada tahun $764 \mathrm{H}$ saat wabah țā'ūn terjadi di Damaskus. Beliau menuturkan, itu terjadi pada tahun 749 H. Semua orang keluar ke tanah lapang beserta pembesar-pembesar negeri, kemudian mereka berdo'a bersama-sama dan beristighatsah. Setelah itu wabah țán'ūn semakin membesar dan semakin banyak penularannya, padahal sebelum mereka menggelar do'a bersama wabah itu masih ringan" (Ahmad bin 'Ali Ibnu Hajar al-'Asqalani t.t., hlm. 328).

Tidak diragukan lagi bahwa meluasnya wabah penyakit seperti dalam kisah di atas adalah disebabkan oleh berbaurnya orang yang positif sakit wabah dengan orang yang masih sehat. Kisah tersebut juga dapat diambil teladan bahwa ketika sedang terjadi wabah penyakit, seseorang harus menjauhi kerumunan banyak manusia dalam suatu tempat. Dengan demikian, tindakan preventif atas 
penyebaran Covid-19 dengan melakukan social distancing sudah cukup tepat, dan bahkan relevan dengan tuntunan Nabi.

Sejauh penelusuran penulis, ada beberapa contoh implementasi social distancing yang umum dilakukan, yakni bekerja dari rumah (work from home), belajar dirumah secara dalam jaringan (online) bagi siswa sekolah dan mahasiswa, menunda pertemuan atau acara yang dihadiri banyak orang, seperti konferensi, seminar, pengajian rutin, tabligh akbar, rapat, dan shalat berjamaah di masjid, serta tidak mengunjungi orang yang sedang sakit cukup melalui telepon atau video call.

Dalam menanggulangi menularnya Covid-19, upaya social distancing ini terbagi menjadi dua, yaitu; pertama, self-quarantine, ditujukan kepada orang yang dinyatakan positif terinfeksi Covid-19. Misalnya seseorang pernah kontak dengan penderita Covid-19, namun belum teridentifikasi gejala. Orang yang termasuk dalam bagian ini harus mengikuti karantina dengan tetap berada di rumah minimal 14 hari. Kedua, self-isolation diberlakukan pada orang yang dinyatakan positif menderita penyakit Covid-19. Bagian ini merupakan upaya penanganan intensif untuk penderita Covid-19 agar mengisolasi diri di ruangan atau kamar khusus, tidak diperkenankan keluar ruangan agar tidak menularkan virus kepada orang lain (Buana, 2020).

\section{Memperbanyak Sedekah}

Ketersediaan harta untuk mengarungi kehidupan pada masa pandemi Covid-19 bisa dibilang tragis. Apalagi pada kondisi keluarga yang sederhana dan pas-pasan dengan indikasi kehilangan pendapatan karena pemutusan hubungan kerja massal, usaha terhenti: dan mengalami pengangguran. Berbeda dengan keluarga yang perekonomiannya terbilang cukup atau bahkan lebih, mereka bisa memanfaatkan harta di tengah pandemi Covid-19 dengan memberi bantuan kepada yang kekurangan. Perbuatan semacam ini sejalan dengan apa yang disampaikan Nabi:

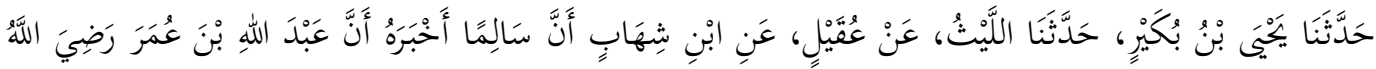

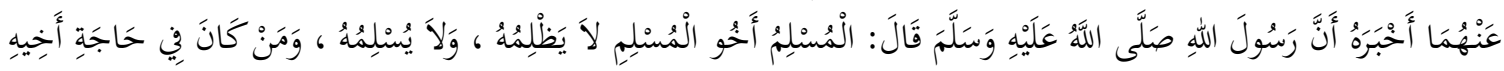

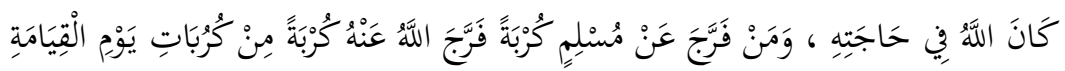

“Muslim satu dengan Muslim lainnya itu bersaudara: maka hendaklah tidak menzalimi: jangan biarkan saudaramu (yang menzalimi atau dizalimi). Siapa yang selalu menolong saudaranya dalam hajatnya: maka Allah akan menolong hajatnya pula. Siapa yang menghilangkan kesulitan seorang Muslim: maka Allah akan menghilangkan kesulitannya dari berbagai kesulitan yang dihadapi pada hari kiamat." (al-Bukhari, 1422, hlm.128).

Hadis ini dapat dijadikan patokan dasar untuk senantiasa membantu orang lain yang kesulitan ditengah pandemi Covid-19. Menolong orang lain yang membutuhkan dengan bersedekah sudah pasti akan diganti berlipat ganda oleh Allah (QS. Sabā' [34]: 39 dan QS. al-An'ām [6]: 160), bahkan selain bersedekah ini mampu menolong orang lain yang kesulitan ditengah pandemi Covid-19, ia juga termasuk salah satu tindakan preventif atas penyeberan Covid-19. Dalam suatu hadis disebutkan:

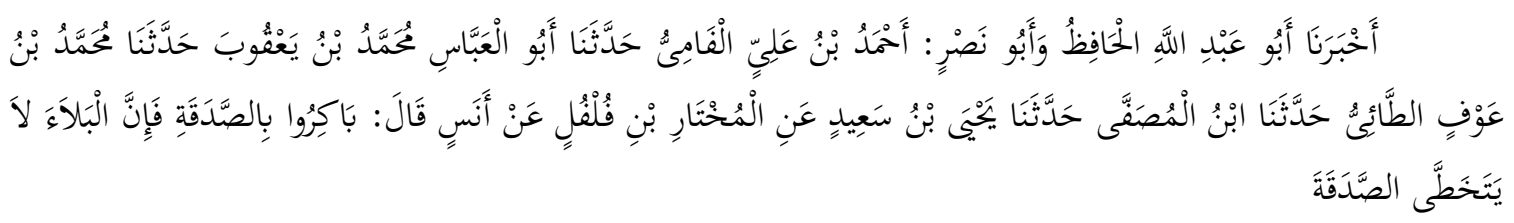

"Bersegeralah bersedekah! Sebab bala bencana tidak pernah mendahului sedekah." (Al-Baihaqiy: 2003, 318).

Penjelasan hadis di atas membuktikan, bahwa sedekah mampu meredam berbagai macam bencana. Meskipun kandungan maknanya mengacu pada bencana secara umum, tetapi bisa digunakan 
sebagai pedoman untuk menangkis penularan bencana penyakit Covid-19. Dengan kata lain: salah satu tindakan preventif atas penyebaran wabah Covid-19 saat ini, salah satunya bisa diatasi dengan memperbanyak sedekah. Bahkan dengan bersedekah akan mampu menghilangkan 70 pintu kejelekan serta membantu mengobati penyakit yang diderita manusia, sebagaimana hadis Nabi berikut ini:

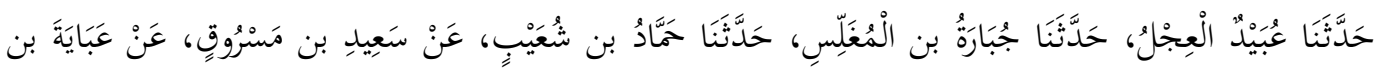

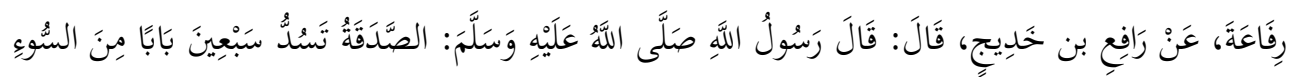

“Sedekah itu bisa menutup 70 pintu keburukan."(Al-Thabraniy: 1994, hlm. 274)

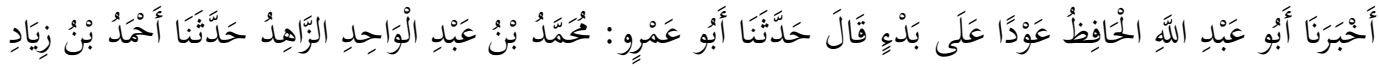

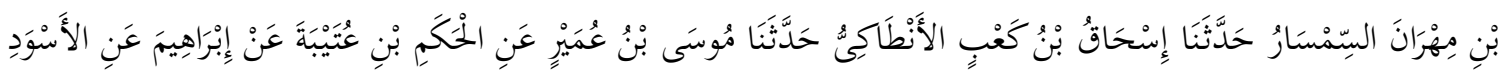

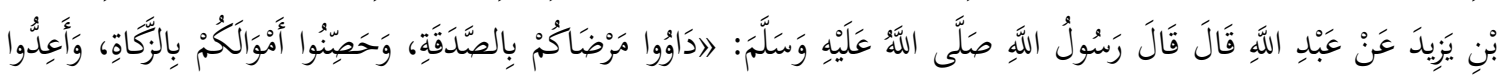

$$
\begin{aligned}
& \text { لِلْبَلاٍَِ الدُّعَاءَ }
\end{aligned}
$$

"Sembuhkanlah orang-orang yang sakit di antara kamu dengan bersedekah: dan bentengilah haratamu dengan mengeluarkan zakat: dan persiapkan Do'a untuk menghadapi datangnya bencana." (Al-Baihaqiy, 2003, hlm. 536)

Kedua hadis di atas mempertegas kekuatan sedekah, bahwa berbagai macam keburukan, bahaya, dan kejelekan dapat diatasi dengan bersedekah. Bahkan penyakit yang diderita seseorang pun bisa sembuh dengan bersedekah (Nurjannah, 2017). Oleh karenanya, menghadapi Covid-19 dapat dicegah dengan memperbanyak sedekah. Dalam hadis lain dikatakan, bahwa sedekah juga mengandung nilainilai sosial di dalamnya:

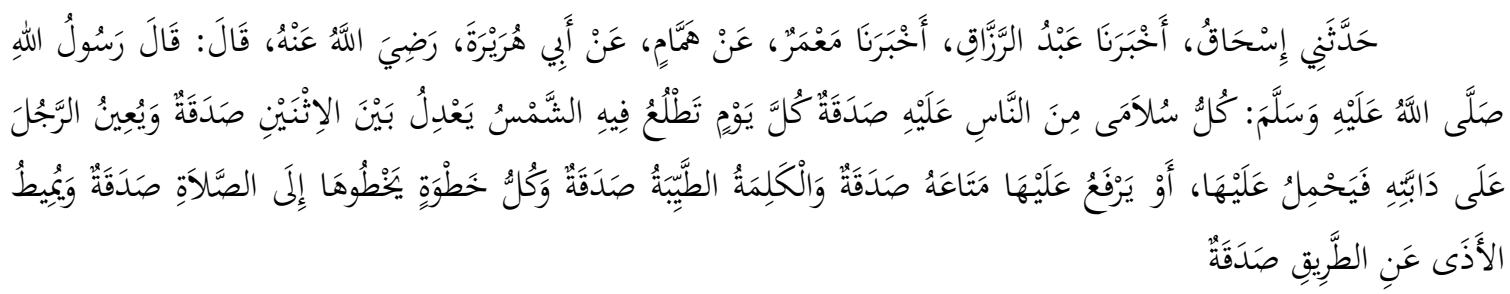

"Setiap anggota badan manusia diwajibkan bersedekah setiap harinya selama matahari masih terbit. Kamu mendamaikan antara dua orang berselisih adalah sedekah. Kamu menolong seseorang naik ke atas kendaraannya atau mengangkat barang bawaannya adalah sedekah. Setiap langkah kakimu menuju tempat shalat juga dihitung sedekah: dan menyingkirkan duri dari jalan adalah sedekah." (al-Bukhari, 1422, hlm. 56).

Hadis ini menjelaskan bahwa sedekah tidak hanya berbentuk harta benda, melainkan perilaku kebaikan yang dapat membawa kemaslahatan sosial. Sedekah dalam konteks ini bisa seperti meredakan dan menghentikan perselisihan, menghindari konflik yang terjadi dalam anggota masyarakat serta saling tolong menolong dalam hal kebaikan. Dengan demikian, penyebaran wabah Covid-19 bisa dilawan dan dibasmi dengan kebersamaan seluruh masyarakat, sesuai dengan posisi dan kemampuang masing-masing. Karena bersedekah tidak hanya berbentuk harta benda, tetapi juga mencakup segala hal yang mendatangkan kebaikan dan kemaslahatan sosial.

Menjaga Imunitas Tubuh

Pada dasarnya, tubuh manusia memiliki sistem imun untuk melawan virus dan bakteri penyebab penyakit. Namun terdapat beberapa hal yang bisa melemahkan sistem imun tersebut, antara lain 
seperti penuaan, kurang gizi, banyak penyakit, dan masih banyak lagi. Oleh karena itu, fungsi sistem imun perlu senantiasa dijaga agar daya tahan tubuh tetap kuat. Karena menjaga imunitas tubuh merupakan salah satu tindakan preventif atas penyebaran Covid-19, serta melindungi tubuh dari berbagai penyakit lainnya. Di antara cara alami untuk menjaga dan memperkuat imunitas tubuh adalah dengan mengkonsumsi makanan dan minuman yang halal. Rasulullah pernah bersabda terkait hal ini,

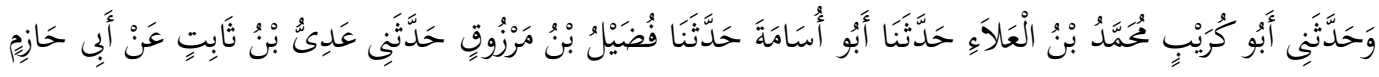

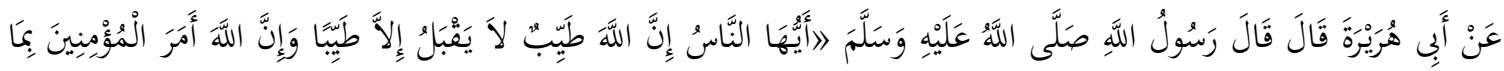

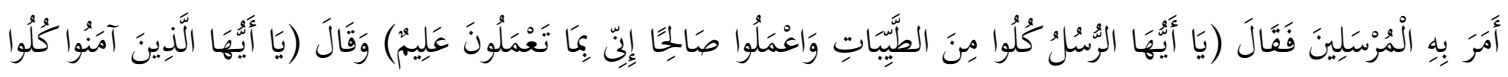

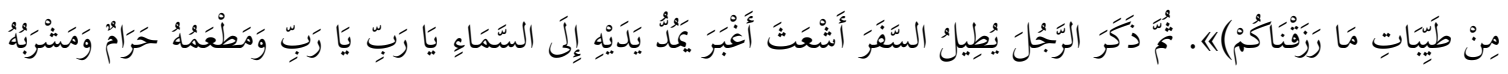

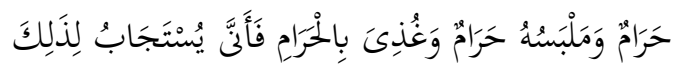

“Wahai sekalian manusia, sesungguhnya Allah itu baik. Dia tidak akan menerima sesuatu melainkan yang baik pula. Dan sesungguhnya Allah telah memerintahkan kepada orang-orang mukmin seperti yang diperintahkan-Nya kepada para Rasul. Firman-Nya: 'Wahai para Rasul! Makanlah makanan yang baik-baik (halal) dan kerjakanlah amal shalih. Sesungguhnya Aku Maha Mengetahui apa yang kamu kerjakan" Dan Allah juga berfirman: 'Wahai orang-orang yang beriman! Makanlah rezeki yang baik-baik yang telah kami rezekikan kepadamu." Kemudian Nabi Saw menceritakan tentang seorang laki-laki yang telah lama berjalan karena jauhnya jarak yang ditempuhnya. Sehingga rambutnya kusut, masai, dan berdebu. Orang itu mengangkat tangannya ke langit seraya berdo'a: "Wahai Tuhanku: wahai Tuhanku." Padahal, makanannya dari barang yang haram, minumannya dari yang haram, pakaiannya dari yang haram dan diberi makan dengan makanan yang haram, maka bagaimanakah Allah akan mengabulkan Do'anya?." (al-Naisaburiy, t.t., hlm. 703).

Di dalam ungkapan hadis ini, terdapat redaksi al-Qur'an surat al-Mu'minūn [23] ayat 51 dan surat al-Baqarah [2] ayat 168, menjelaskan tentang perintah untuk mengkonsumsi makanan yang halāl dan țayyib. Redaksi perintah ini menurut Ibn Kathīr menunjukkan perintah wajib yang harus ditaati oleh setiap hamba Allah yang beriman. Allah telah memerintahkan kepada setiap hamba-Nya untuk senantiasa mengkonsumsi makanan yang halal agar do'a dikabulkan dan amal ibadah dapat diterima. Hal ini mengandung arti bahwa umat Islam dilarang sepenuhnya untuk mengkonsumsi makanan dan minuman yang haram atau tidak jelas kehalalannya, seperti mengkonsumsi kelelawar, ular, tikus, dan sejenisnya.

Sebagaimana telah diketahui, analisis terbaru para ilmuwan China menunjukkan Covid-19 ditularkan dari kelelawar ke ular kemudian ke manusia. Sup kelelawar di daerah Wuhan China merupakan hidangan yang sangat populer dan spesifik serta sangat disukai. Tidak hanya kelelawar, ular juga diduga penyebab penyebaran Covid-19. Ular sering berburu kelelawar di alam liar, sementara laporan menunjukkan bahwa ular dijual di pasar makanan laut lokal di Wuhan meningkat. Kemungkinan tahun 2019 merupakan awal dari adanya wabah Covid-19 yang menjalar dari spesies kelelawar menjadi ular dan kemudian ke tubuh manusia (Yang et al., 2020).

Kandungan makna yang termaktub dalam hadis di atas, tampaknya sangat relevan dengan kondisi masyarakat yang sembarangan mengkonsumsi makanan. Covid-19 adalah bukti nyata hasil konsumsi yang tidak jelas kehalalannya atau jelas keharamannya. Oleh karena itu, mengkonsumsi makanan yang halal secara dzat sangat dianjurkan oleh Islam, terlebih makanan yang bergizi akan mampu meningkatkan sistem imunitas tubuh manusia (Husna, 2020).

Di samping itu, agar tidak mudah tertular Covid-19 dan sistem imun serta kesehatan tetap terjaga, seseorang ketika bersin diharuskan untuk menunduk, menutup mulut dan hidung, serta mengucapkan 
rasa syukur. Ini dimaksudkan untuk mencegah penyebaran Covid-19 sekaligus saling mendo'akan, sebagaimana petunjuk Nabi dalam sebuah hadis:

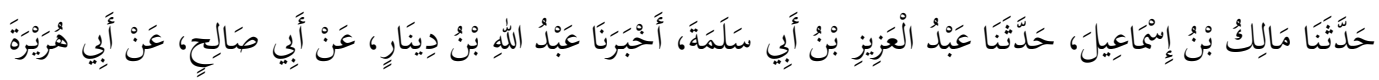

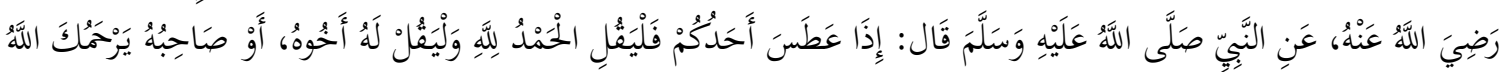

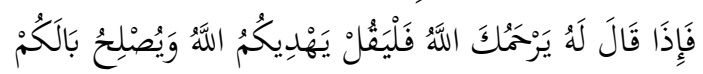

"Jika salah seorang di antara kalian bersin: maka ucapkanlah Alhamdulillah (segala puji bagi Allah), dan hendaklah saudaranya (yang mendengar) mengucapkan yarhamkallah (semoga Allah merahmatimu). Jika ia mengucapkan yarhamkallah, maka ucapkanlah yahdīkumullāh wa yuṣlị bālakum (semoga Allah memberikan petunjuk dan memperbaiki keadaanmu)." (al-Bukhari, 1422, hlm. 49).

Menurut Ibn al-Qayyīm al-Jauziyyah, sunnah bagi orang yang bersin mengucapkan alhamdulillāh karena merupakan nikmat yang menunjukkan keringat badannya (fresh) dan keluarnya uap yang berat. Namun, bersin juga dapat menularkan berbagai bakteri atau penyakit bagi yang mengidap penyakit, termasuk penyakit Covid-19. Oleh karenanya, penting bagi setiap orang untuk mengamalkan hadis tersebut ditengah pandemi Covid-19, terlebih juga menerapkan protokol kesehatan sesuai dengan yang dianjurkan pemerintah, yakni menggunakan masker agar lebih terjaga.

Selain mengkonsumsi makanan halal dan bergizi serta menjaga kesehatan, terdapat cara lain untuk menjaga imunitas tubuh, yakni giat berolahraga. Nabi pernah mencontohkan olahraga jalan kaki dan berlari untuk mempertahankan imunitas tubuh, antara lain:

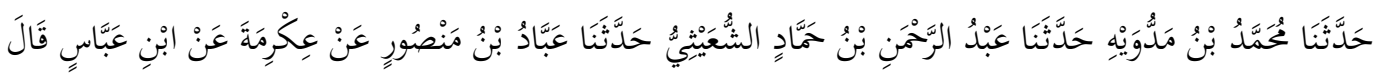

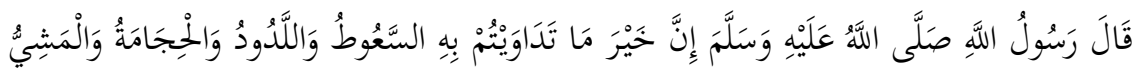

"Sebaik-baik aktivitas untuk mengobati diri ialah mengobati diri melalui hidung (gurah), ladūd (obat yang diteteskan disisi mulut), berbekam, dan al-mashi (jalan kaki)." (Al-Tirmidzy, 1996: 456)

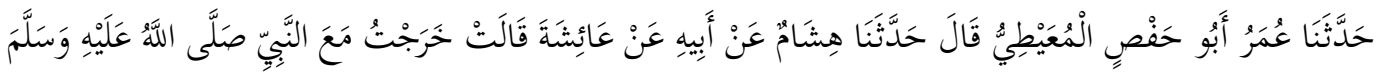

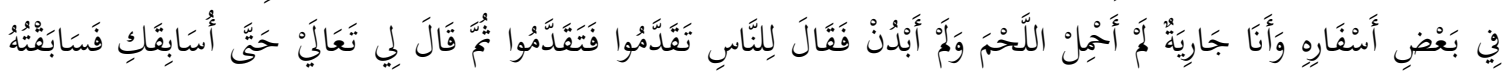

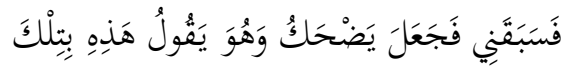

"Aku pernah pergi bersama Nabi Saw dan saat itu aku masih kurus. Ketika kami telah sampai di suatu tempat, beliau berujar kepada para sahabat; 'Majulah'! mereka pun maju. Kemudian beliau berkata kepadaku; 'Kemarilah kepadaku, aku akan mengajakmu lomba berlari dan aku akan memenanginya.' Awalnya aku mendahului beliau, tapi kemudian beliau mendahuluiku sehingga membuat beliau tertawa dan berkata; 'Ini dengan itu'." (Ahmad bin Hanbal, 1999, hlm. 313).

Kedua hadis di atas membuktikan, bahwa Nabi pernah mengajarkan kepada umatnya untuk senantiasa giat berolahraga. Jalan kaki dan berlari-lari selama 30 menit sehari, menurut dunia kesehatan terbukti mampu memperkuat tulang dan menurunkan risiko hipertensi, serangan jantung, dan diabetes. Dengan demikian, apa yang dicontohkan Nabi dalam hadis yang tercantum di atas, setidaknya dapat dijadikan teladan untuk menjaga dan memperkuat imunitas tubuh agar tidak mudah tertular wabah Covid-19. 
Selalu memelihara wudhu ( $\left(\bar{a}^{\prime} i m\right.$ al-wuḍu')

Sebagaimana yang telah digaungkan pemerintah terkait penanggulangan Covid-19, masyarakat dianjurkan untuk senantiasa menjaga dan memperhatikan kebersihan. Kondisi bersih pada dasarnya mengarah pada aspek ibadah dan aspek moral yang tidak hanya merupakan slogan atau teori belaka, tetapi harus dijadikan pola hidup praktis yang mendidik setiap manusia untuk selalu hidup bersih sepanjang masa. Hidup bersih dalam pandangan Islam merupakan sebagian dari iman. Oleh karenanya, kualitas iman seseorang tidak hanya diukur dari banyaknya kuantitas ritual ibadah, tetapi juga menjaga kebersihan merupakan hal yang sangat fundamental dalam kesempurnaan iman seseorang. Disebutkan dalam hadis Nabi:

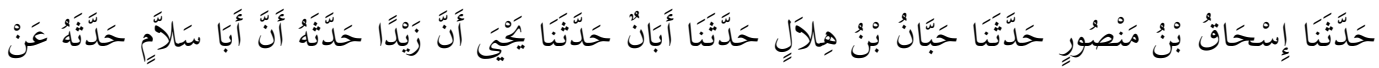

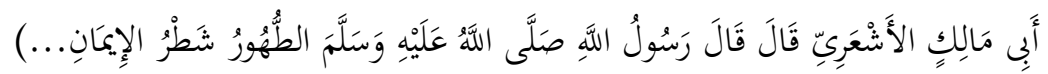

"Kebersihan adalah sebagian dari iman." (al-Naisaburiy, t.t., hlm. 203)

Secara eksplisit, ungkapan hadis ini mengandung makna agar umat Islam senantiasa menjaga kebersihan yang termasuk bagian dari iman. Hidup bersih dan suci bisa dilakukan dengan sering berwudhu yang mengharuskan umat Islam selalu mencuci tangan dan membasuh wajah serta anggota tubuh lainnya (Musbikin, 2009, hlm.15). Ini merupakan salah satu tindakan preventif agar terhindar dari berbagai virus maupun kuman penyakit. Selain wudhu dapat membersihkan diri dari segala macam kotoran yang menempel pada tubuh, ia juga bisa menjadikan pengampunan dosa bagi yang terjaga wudhunya, sebagaimana hadis Nabi berikut ini:

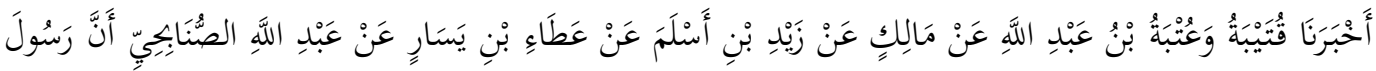

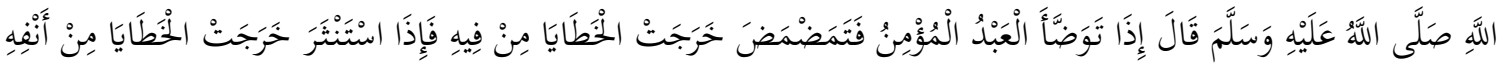

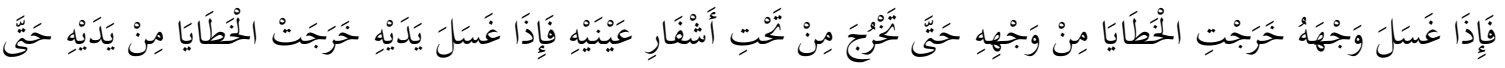

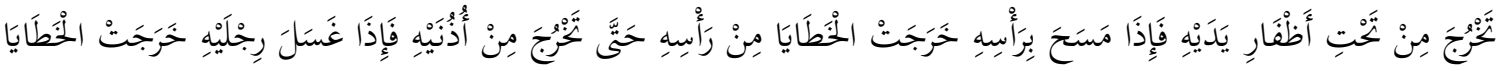

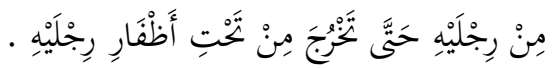

Rasulullah Saw bersabda: "Apabila seorang hamba yang beriman berwudlu lalu ia berkumurkumur: maka keluarlah kesalahan kesalahan yang diperbuat oleh mulutnya. Bila dia menghirup air ke dalam hidung lalu mengeluarkannya, maka keluarlah kesalahan dari hidungnya. Bila membasuh muka, keluarlah kesalahan dari mukanya hingga keluar dari kedua kelopak matanya. Jika ia membasuh kedua tangannya: maka keluarlah kesalahannya dari kedua tangannya hingga keluar dari bawah kuku-kuku kedua tangannya. Apabila mengusap kepalanya, maka keluarlah kesalahannya dari kepalanya hingga keluar dari kedua telinganya, dan apabila membasuh kedua kakinya, maka keluarlah kesalahan dari kedua kakinya hingga dari bawah kedua kuku-kuku kedua kakinya." (al-Nasa'i, 1986, hlm. 74)

Hadis ini menjelaskan rangkaian basuhan wudhu yang besertaan dengan ampunan dosa terhadap anggota tubuh yang dibasuh. Secara spesifik, anggota yang dibasuh saat wudhu dalam perspektif hadis di atas adalah anggota mulut, rongga hidung, seluruh wajah, kedua tangan, sebagian kepala termasuk telinga, dan juga kedua kaki. Jika seseorang selalu memperbaharui wudhu saat hadas/tidak suci, maka anggota-anggota tersebut sudah pasti akan terbasuh. Di samping itu, merutinkan wudhu secara terus-menerus atau selalu bersuci ketika sedang hadas/najis akan menghentikan penularan bakteri atau virus. Karena pada dasarnya virus dapat menular melalui udara yang melewati salur pernafasan dan banyak terdapat di lubang hidung dan mulut, sementara dengan berwudhu sudah pasti melakukan cuci tangan, berkumur-kumur, dan membersih rongga hidung (Adilia, 2020). Dengan 
demikian, memelihara wudhu secara rutin merupakan salah satu cara menjaga kebersihan tubuh agar terhindar dari penularan dan penyebaran Covid-19.

Memohon perlindungan kepada Allah

Dalam ajaran Islam, setiap umatnya telah dianjurkan untuk senantiasa beribadah kepada Allah melalui Do'a. Ajaran Islam terkait berdo'a ini termuat dalam beberapa ayat al-Qur'an, penjelasan hadis Nabi, dan uraian kitab-kitab klasik. Setiap do'a yang dipanjatkan kepada Allah dengan yakin, tulus, dan ikhlas, sudah pasti akan dikabulkan oleh Allah Swt. Ini terungkap dalam QS. al-Mu'min ayat 60; "Dan Tuhanmu berfirman, berdo'alah kepada-Ku, niscaya akan Kukabulkan bagimu".

Dalam konteks menanggulangi wabah Covid-19, memohon perlindungan kepada Allah melalui do'a merupakan cara terkahir untuk menghindari penularan virus tersebut. Selain alasan setiap do'a pasti akan dikabulkan oleh Allah sebagaimana uraian di atas, juga karena berdo'a merupakan bentuk tawakkal kepada Allah setelah sebelumnya ber-ikhtiar secara maksimal. Nabi Saw pernah mengajarkan kepada umatnya untuk memperbanyak do'a saat melihat atau bertemu dengan orang yang sedang tertimpa musibah atau bencana. Do'a yang dipanjatkan agar terhindar dari bencana atau petaka adalah sebagaimana dalam hadis berikut:

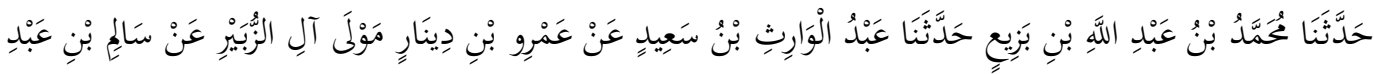

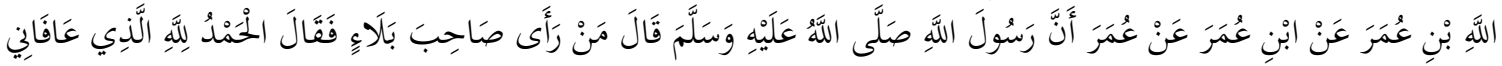

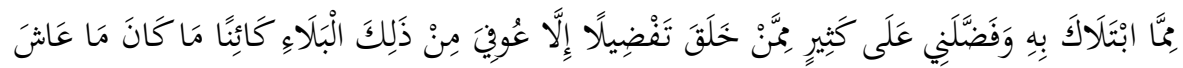

“Barang siapa melihat orang yang tertimpa musibah kemudian berdo'a: al-ḥamdulillāh al-ladhī 'āfānī mimmā ibtalāka bihi wa faz̧z̧alanī 'alā kathīrin mimman khalaqa taf̣̣īlā (segala puji bagi Allah yang telah menyelamatkanku dari musibah yang telah menimpamu: dan memberikan anugerah kepadaku atas kebanyakan makhluk yang Dia ciptakan) kecuali ia diselamatkan dari ujian tersebut, apapun hal tersebut selama ia masih hiduhlm." (Al-Tirmidhī, 1975, hlm. 493).

Apa yang dicontohkan Nabi terkait do'a bersyukur atas keselamatan dari musibah ini bisa dijadikan pedoman di tengah pandemi Covid-19. Umat Islam harus senantiasa berdo'a memohon pertolongan kepada Allah agar tidak terjangkit berbagai penyakit dan virus. Ini termasuk tindakan preventif atas penyebaran Covid-19 yang dilakukan secara bathin. Terkait dengan ini: para ulama juga telah banyak memberikan sumbangsih do'a untuk menanggulangi penularan Covid-19, di antaranya:

Pertama, Do'a dari hạạrat al-shaikh KH. Hasyim Asy'ari Jombang dan para masyayikh pesantren Lirboyo Kediri: dengan membaca:

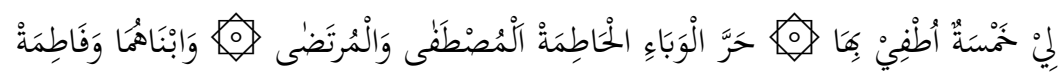

Do'a ini dibaca sebanyak-banyaknya selama wabah Covid-19

Kedua, Himbauan untuk berdo'a dari Pengurus Besar Nahdlatul Ulama (PBNU) dan Habib Taufiq Pasuruan, dengan membaca:

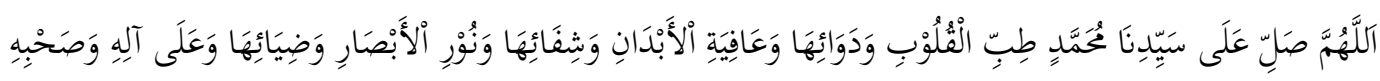

Do'a sholawat ini dianjurkan untuk dibaca selama wabah Covid-19: yakni setelah shalat maktubah sebanyak 11 kali.

Ketiga, Do'a dari Habib Luthfi bin Yahya Pekalongan: yaitu: 


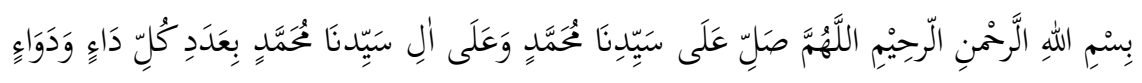

Do'a sholawat ini diamalkan untuk menanggulangi Covid-19: dibaca setelah shalat maktubah sebanyak 11 kali.

Keempat, Do'a dari Masyayikh pesantren Ploso Kediri, yakni membaca istighfar (memohon ampun kepada Allah) sebanyak 25 kali setelah shalat maktubah. Kemudian membaca Do'a berikut ini:

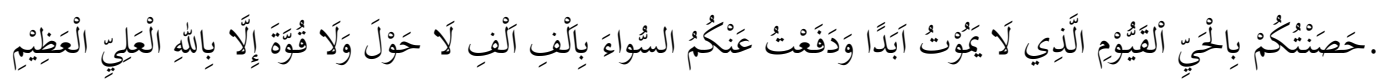

Kelima, Do'a dari Alm. KH. Maimun Zubair Sarang Rembang: dengan membaca QS. al-Isra' [17]: 82 sebagai berikut:

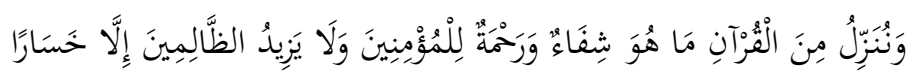

Ayat ini dibaca sebelum tidur sebanyak 11 kali, kemudian ditiupkan ke telapak tangan dan diusapkan ke seluruh bagian tubuh.

Selain do'a yang telah disebutkan di atas, sebenarnya masih banyak lagi do'a yang belum penulis cantumkan. Selain keterbatasan ruang dan waktu, juga karena eksplorasi do'a di atas sudah cukup representatif untuk diamalkan dalam rangka memohon perlindungan kepada Allah agar tidak tertular Covid-19. Dengan demikian, masyarakat Indonesia hanya tinggal mengikuti arahan yang digaungkan pemerintah dengan menerapkan protokol kesehatan, stay at home dan social distancing, serta juga anjuran dari para habaib dan ulama dengan mengamalkan berbagai do'a yang telah ditawarkan. Hal ini urgen dilakukan, mengingat penyebaran Covid-19 semakin meluas dan angka kematian semakin meningkat tajam. Selain itu, tindakan preventif atas penyebaran wabah Covid-19 di atas juga telah sesuai dengan ajaran Islam, di mana masyarakat diperintahkan untuk ber-ikhtiar secara dzahir dan juga secara bathin.

\section{Kesimpulan}

Dari pemaparan yang relatif singkat di atas, dapat disimpulkan bahwa Islam telah memberi rambu-rambu tindakan preventif atas segala macam penyakit dan bencana melalui tuntunan Nabi Muhammad jauh sebelum Covid-19 muncul. Bahkan apa yang dituturkan Nabi Saw sangat relevan dengan anjuran yang digaungkan pemerintah. Ini penting untuk diteladani dan diterapkan ditengah pandemi Covid-19 saat ini, bahwa upaya mencegah Covid-19 dalam perspektif hadis ada enam, antara lain; berdiam dirumah, jaga jarak dengan pembatasan social, menolong orang lain dengan memperbanyak sedekah, selalu dalam kondisi bersih dengan merutinkan dan memelihara wudhu, menjaga imunitas tubuh dengan mengkonsumsi makanan dan minuman halal, menjaga kesehatan serta giat berolahraga, dan terakhir berdo'a memohon pertolongan kepada Allah Swt. Tentu saja, tindakan preventif atas penyebaran Covid-19 ini merupakan ikhtiar yang harus dilakukan secara intens dan kolektif setiap warga.

\section{Daftar Pustaka}

Adilia, T. (2020, March 16). Wudhu Yang Diyakini Sebagai Upaya Mencegah Virus Corona. Republika. Ahmad bin Hanbal. (1999). Musnad Ahmad Bin Hanbal (S. Al-Arnauthiy, Ed.). Mu'assasah Risalah. al-'Asqalani, Ahmad bin 'Ali Ibn Hajar. (1982). Fath al-Bari bi Syarh Shahih al-Bukhari (Vol. 10). Beirut: Ihya' al-Turats al-'Arabi.

al-'Asqalani, Ahmad bin 'Ali Ibnu Hajar. (t.t.). Badzl al-Ma'un Fi Fadhli al-Tha'un. Riyadh: Dar al-'Ashimah. al-Bukhari, M. bin I. A. 'Abdullah. (1422). Shahih al-Bukhari (Vol. 9). Damaskus: Dar Tuq al-Najah. al-Naisaburiy, M. bin H. (t.t.). Shahih Muslim (Vol. 2). Beirut: Dar Ihya al-Turats al-'Arabi.

Al-Baihaqiy, A. ibn al-H. ibn 'Aliy. (2003). As-Sunan al-Kubra (M. 'Abd al-Qadir 'Atha, Ed.). Beirut: Dar al-Kutub al-Ilmiyyah. 
al-Nasa'i, A. abdurahman ahmad bin S. bin ali al-khurasani. (1986). Sunan al-Nasa'i. Halb: Maktabah al-Matbuat al-Islamiyah.

Al-Nawawi, A. Z. Y. M. bin S. (1392). al-Minhâj: Syarah Shahih Muslim (Vol. 15). Beirut: dar Ihya al-Turats al-Arabi.

Al-Qasthalaniy, A. ibn M. S. ad-Din. (1323). Irsyad as-Sari li Syarh Shahih al-Bukhariy. Mesir: al-Matba'ah al-Kubra al-Amiriyah.

At-Thabraniy, S. ibn A. ibn A. (1994). Al-Mu'jam al-Kabir (H. ibn 'Abd al-Majid As-Salafiy, Ed.). Kairo: Maktabah Ibn Taimiyah.

At-Tirmidzy, I. (1996). Sunan at-Tirmidzy. Beirut: Darul Ghorb Al-Islamy.

Azanella, L. A. (2020, April 1). Virus Corona: Efek ke Sistem Pernapasan, Gejala, dan Orang Paling Berisiko Terinfeksi Covid-19. Retrieved April 1, 2020, from https://www.kompas.com/tren/read/2020/04/01/202500365/virus-corona-efek-ke-sistem-pernapasan-gejaladan-orang-paling-berisiko?page=1

Buana, D. R. (2020). Analisis Perilaku Masyarakat Indonesia dalam Menghadapi Pandemi Virus Corona (Covid19) dan Kiat Menjaga Kesejahteraan Jiwa. SALAM: Jurnal Sosial Dan Budaya Syar-i, 7(3).

CNN Indonesia. (2020). Ahli AS: Masa Inkubasi Virus Corona Covid-19 Selama 5 Hari. Retrieved September 29, 2020, from https:/www.cnnindonesia.com/teknologi/20200319125940-199-484943/ahli-as-masa-inkubasivirus-corona-covid-19-selama-5-hari

Husna, F. (2020). Virus Corona Dampak dari Makanan yang tidak Halal. SALAM: Jurnal Sosial Dan Budaya Syar-i, 7(6). https://doi.org/10.15408/sjsbs.v7i6.15318

Ibnu Baththal, A. al-H. A. (2003). Syarh Shahih al-Bukhari (Vol. 9). Riyadh: Dar al-Nasyr.

Kementerian Kesehatan Republik Indonesia. (2020). Info Corona Virus Archives» Info Infeksi Emerging Kementerian Kesehatan RI. Retrieved September 29, 2020, from https:/covid19.kemkes.go.id/category/situasi-infeksi-emerging/info-corona-virus/

Mukaromah, I. F. (2020, April 1). Apa Itu Virus Corona, yang Jadi Penyebab Penyakit Covid-19, MERS, dan SARS. Periksa,. Retrieved from https://www.kompas.com/tren/read/2020/03/17/153000465/apa-itu-virus-coronayang-jadi-penyebab-penyakit-covid-19-mers-dan-sars?page=1.

Musbikin, I. (2009). Wudhu Sebagai Terapi Upaya Memelihara Kesehatan Jasmani dengan Perawatan Ruhani. Yogyakarta: Nusamedia.

Nugroho, W. D., Cahyani, W. I., Tobing, A. S., Istiqomah, N., Cahyasari, I., Indrastuti, M., ... Isworo, A. (2020). Literature Review: Transmisi Covid-19 dari Manusia ke Manusia di Asia. Journal of Bionursing, 2(2), 101-112.

Nurjannah, S. (2017). Living hadis: tradisi rebo wekasan di pondok pesantren mqhs al-kamaliyah babakan ciwaringin cirebon. Diya Al-Afkar: Jurnal Studi al-Quran Dan al-Hadis, 5(01), 219.

Pentingnya menerapkan social distancing demi mencegah-covid-19,. (2020, April 2). Retrieved April 2, 2020, from https://www.alodokter.com/pentingnya-menerapkan-social-distancing-demi-mencegah-covid-19

Primandya, A. (2020, March 28). Masa Kecil Nabi, Wabah dan Sejarah. Retrieved March 28, 2020, from https://neswa.id/artikel/masa-kecil-nabi-wabah-dan-sejarah/

Putri, G. S. (2020, April 5). Gambar Virus Corona Wuhan Covid-19 Dirilis, Begini Penampakannya. Diakses. Retrieved April 5, 2020, from https://sains.kompas.com/read/2020/02/14/105014823/gambar-virus-coronawuhan-covid-19-dirilis-begini-penampakannya

Qudsy, S. Z., \& Sholahuddin, A. (2020). Kredibilitas Hadis dalam COVID-19: Studi atas Bażl al-Mā' ūn fi Fadhli alThāun karya Ibnu Hajar al-Asqalany. AL QUDS : Jurnal Studi Alquran Dan Hadis, 4(1), 1. Rusdi, R. (2020). Pandemi Penyakit dalam Sejarah dan Dampaknya Terhadap Gejolak Sosial Politik. Diakronika, 20(1), 50. https://doi.org/10.24036/diakronika/vol20-iss1/146

Shereen, M. A., Khan, S., Kazmi, A., Bashir, N., \& Siddique, R. (2020). COVID-19 infection: Origin, transmission, and characteristics of human coronaviruses. Journal of Advanced Research, 24, 91-98. Telaumbanua, D. (2020). Urgensi Pembentukan Aturan Terkait Pencegahan Covid-19 Di Indonesia. QALAMUNA: Jurnal Pendidikan, Sosial, Dan Agama, 12(1), 59-70.

Yang, J., Zheng, Y., Gou, X., Pu, K., Chen, Z., Guo, Q., ... Zhou, Y. (2020). Prevalence of comorbidities in the novel Wuhan coronavirus (COVID-19) infection: A systematic review and meta-analysis. International Journal of Infectious Diseases.

Zahrotunnimah, Z. (2020). Langkah Taktis Pemerintah Daerah Dalam Pencegahan Penyebaran Virus Corona Covid-19 di Indonesia. SALAM: Jurnal Sosial Dan Budaya Syar-i, 7(3). https://doi.org/10.15408/sjsbs.v7i3.15103

(C) 2020 by the authors. It was submitted for possible open access publication under the terms and conditions of the Creative Commons Attribution (CC BY SA) license (https://creativecommons.org/licenses/by-sa/3.0/). 